Published in final edited form as:

Anal Chem. 2019 January 15; 91(2): 1441-1451. doi:10.1021/acs.analchem.8b04258.

\title{
Carrier-Assisted Single-Tube Processing Approach for Targeted Proteomics Analysis of Low Numbers of Mammalian Cells
}

\author{
Pengfei Zhang ${ }^{\dagger,}$, Matthew J. Gaffrey ${ }^{\ddagger}$, Ying Zhu§, William B. Chrisler ${ }^{\ddagger}$, Thomas L. \\ Fillmore ${ }^{\S}$, Lian $\mathrm{Yi}^{\ddagger}$, Carrie D. Nicora ${ }^{\ddagger}$, Tong Zhang ${ }^{\ddagger}$, Huanming $\mathrm{Wu}^{\ddagger}$, Jon Jacobs ${ }^{\ddagger}$, Keqi \\ Tang ${ }^{\ddagger}$, Jacob Kagan", Sudhir Srivastava", Karin D. Rodland ${ }^{\ddagger}$, Wei-Jun Qian ${ }^{\ddagger}$, Richard D. \\ Smith ${ }^{\ddagger}$, Tao Liu ${ }^{\ddagger}$, H. Steven Wiley ${ }^{\S}$, and Tujin Shi ${ }^{\star}, \ddagger$ \\ tKey Laboratory of Cancer Proteomics of Chinese Ministry of Health, Xiangya Hospital, Central \\ South University, Changsha, Hunan 410008, People's Republic of China \\ ‡Biological Sciences Division, Pacific Northwest National Laboratory, Richland, Washington \\ 99354, United States \\ §Environmental Molecular Sciences Laboratory, Pacific Northwest National Laboratory, Richland, \\ Washington 99354, United States \\ "Cancer Biomarkers Research Group, Division of Cancer Prevention, National Cancer Institute, \\ Bethesda, Maryland 20892, United States
}

\begin{abstract}
Heterogeneity in composition is inherent in all cell populations, even those containing a single cell type. Single-cell proteomics characterization of cell heterogeneity is currently achieved by antibody-based technologies, which are limited by the availability of high-quality antibodies. Herein we report a simple, easily implemented, mass spectrometry (MS)- based targeted proteomics approach, termed cLC-SRM (carrier-assisted liquid chromatography coupled to selected reaction monitoring), for reliable multiplexed quantification of proteins in low numbers of mammalian cells. We combine a new single-tube digestion protocol to process low numbers of cells with minimal loss together with sensitive LC-SRM for protein quantification. This singletube protocol builds upon trifluoroethanol digestion and further minimizes sample losses by tube pretreatment and the addition of carrier proteins. We also optimized the denaturing temperature and trypsin concentration to significantly improve digestion efficiency. cLC-SRM was demonstrated to have sufficient sensitivity for reproducible detection of most epidermal growth
\end{abstract}

\footnotetext{
*Corresponding Author Phone: 509-371-6579. tujin.shi@ pnnl.gov.

Supporting Information

The Supporting Information is available free of charge on the ACS Publications website at DOI: 10.1021/acs.analchem.8b04258. SRM assays for EGFR pathway proteins, copy numbers of EGFR pathway proteins in a panel of cell lines, quantification of EGFR pathway proteins in small numbers of MCF cell equivalents, evaluation of processing reproducibility of cLC-SRM, and EGFR pathway protein quantification in FACS-isolated 10 and 100 MCF7 cells (XLSX)

Full scan analysis of digestion of different amounts of BSA, LC-MS/MS analysis of MCF7 lysate digests, XICs and calibration curve for PEBP1, H/K/NRAS, K/NRAS, NRAS, GRB2, MAP2K2, PTPN11, ADAM17, CBL, and AKT1, XICs for pathway protein quantification in FACS-isolated 10 and 100 MCF7 cells, selected EGFR pathway proteins for optimization of the TFE digestion protocol and generation of calibration curves, SRM S/N ratio of target peptides in 5-200 MCF7 cell equivalents and intact 10 and 100 MCF7 cells, and supplemental methods (PDF)

The authors declare no competing financial interest.

The Skyline-processed SRM results reported in this study can be accessed at Panorama (https://panoramaweb.org/gTHtkA.url.
} 
factor receptor (EGFR) pathway proteins expressed at levels $\geq 30000$ and $\geq 3000$ copies per cell for 10 and 100 mammalian cells, respectively. Thus, cLC-SRM enables reliable quantification of low to moderately abundant proteins in less than 100 cells and could be broadly useful for multiplexed quantification of important proteins in small subpopulations of cells or in size-limited clinical samples. Further improvements of this method could eventually enable targeted single-cell proteomics when combined with either SRM or other emerging ultrasensitive MS detection.

\section{Graphical Abstract}

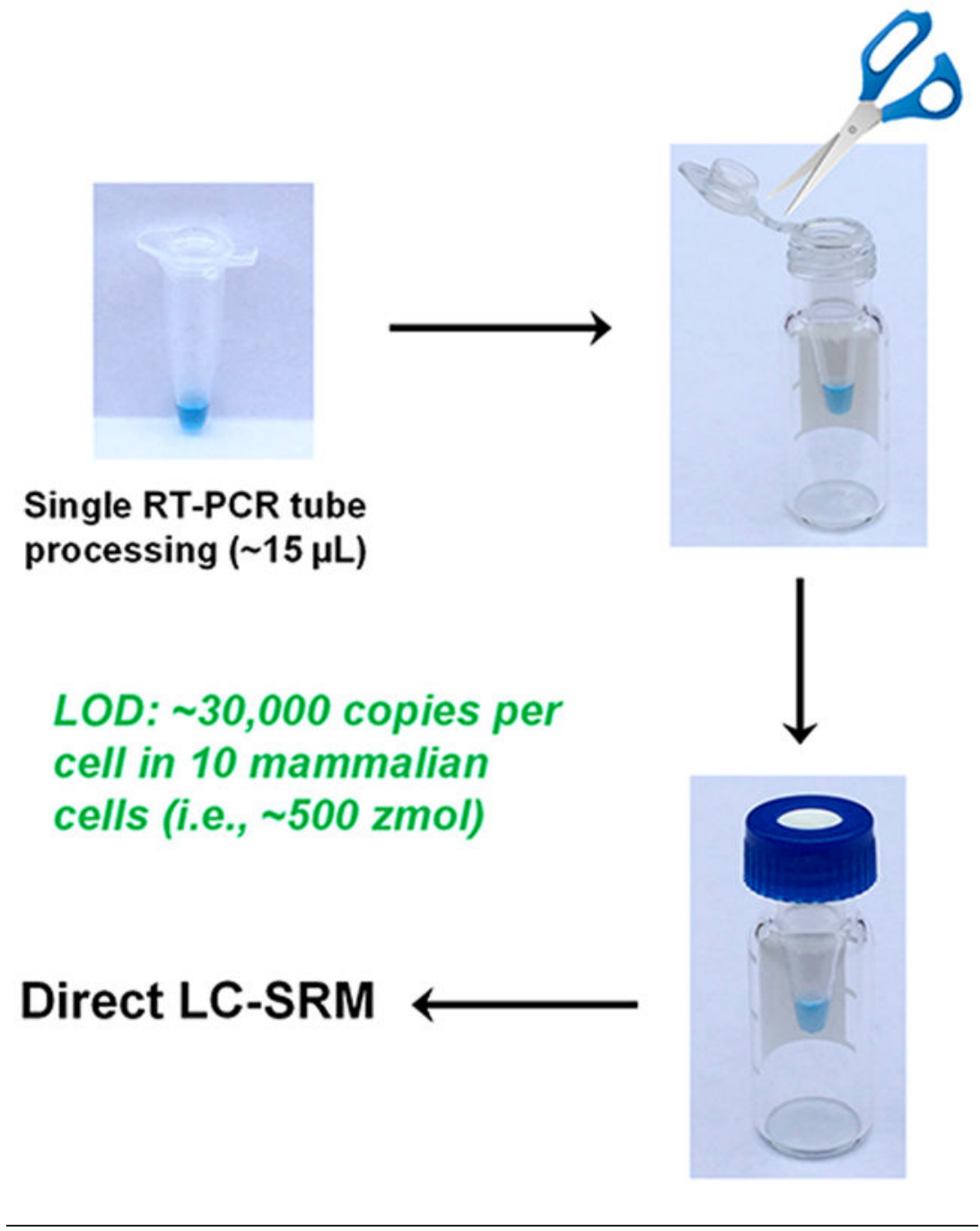

Cell heterogeneity (i.e., single-cell variability) is a characteristic feature of all living organisms and inherent in cellular processes. ${ }^{1-4}$ Multiomics technologies that enable comprehensive characterization of a broad spectrum of subpopulations of tumor cells at single-cell resolution are crucial to achieve a complete picture of tumor heterogeneity at both the genotype and phenotype levels. ${ }^{5-9}$ Furthermore, clinically important specimens are often available only in low amounts (e.g., $\leq 10$ tumor cells from needle biopsies), which require using advanced ultrasensitive single-cell platforms for their effective analysis. ${ }^{7-9}$ Recent advances in nucleic acid sequencing technologies allow for deep characterization of 
genomes and transcriptomes of single cells. ${ }^{10,11}$ However, single-cell proteomics technologies are lagging far behind. ${ }^{3,6,12-14}$ Currently, single-cell proteomics measurements exclusively rely on antibody-based targeted immunoassays. ${ }^{3,15}$ This approach has inherent limitations, such as low multiplexing capability and the need to generate high-specificity antibodies, especially for protein mutations and posttranslational modifications.

Mass spectrometry (MS)-based targeted proteomics is highly promising for single-cell proteomics analysis because it is antibody-free and has high multiplexing capability, as well as very high specificity and quantitation precision/accuracy. ${ }^{16}$ With recent advances in separations and MS instrumentation, the most sensitive MS platforms can detect peptides at 10-100 zmol (i.e., 6000-60 000 molecules), and potentially much lower, ${ }^{17-19}$ thus enabling the analysis of subnanogram amounts of peptide mixtures. ${ }^{20-26}$ In theory, such sensitivity is sufficient to quantify $\sim 25-55 \%$ of the whole proteome of a single mammalian cell (i.e., $\sim 4000-8500$ proteins out of $\sim 15000$ proteins in a single HeLa cell ${ }^{27}$ ) assuming $100 \%$ sample recovery during sample processing and high-efficiency ion generation and transmission to the MS. However, there is an unmet technical challenge in sample preparation for effective processing of single mammalian cells for MS analysis.

Single-cell MS has been implemented for proteomic analysis of very large single cells, ${ }^{28-33}$ such as early stage embryo cells or oocytes that are $\sim 100-1000 \mu \mathrm{m}$ in diameter and contain $\sim 0.1-100 \mu \mathrm{g}$ of proteins per cell. ${ }^{34}$ It is a much greater challenge to apply these techniques to typical single mammalian cells as most are $\sim 10-100$-fold smaller in diameter with $\sim 103-$ 106 -fold less protein content (i.e., $\sim 10 \mu \mathrm{m}$ in diameter and $\sim 100 \mathrm{pg}$ per cell). Recent progress in mass-limited sample processing (e.g., single-tube preparation and online processing $)^{35,36}$ has been reported for effective processing of hundreds and thousands of mammalian cells (i.e., 10-1000 ng of total protein) with identification of $\sim 1000-3000^{20,36}$ and $\sim 3000-4000$ proteins, ${ }^{22,32,37-39}$ respectively. Nevertheless, when sample size becomes smaller (close to single-cell levels), there are increasingly significant losses through contactsurface adsorption, especially with sample processing volumes in the range of 10-100 $\mu \mathrm{L}$. To significantly minimize surface loss, our group has made significant progress in the development of a nanoPOTS (nanodroplet processing in one pot for trace samples) platform with downscaling of the processing volume to $<200 \mathrm{~nL} .{ }^{36}$ When combined with ultrasensitive liquid chromatography-mass spectrometry (LC-MS), nanoPOTS has recently allowed us to identify $\sim 670$ and $\sim 1500-3000$ proteins from single and $\sim 10-140$ mammalian cells, respectively. ${ }^{36,40}$ However, at its current stage of development nanoPOTS is not easily adoptable by other MS-based proteomics laboratories.

To alleviate this situation, we have been exploring alternative more translatable approaches, including the use of exogenous carrier proteins to minimize sample loss, to provide more easily implementable approaches for MS-based proteomics. For example, we have recently developed a facile targeted mass spectrometric approach, termed cPRISM-SRM (carrierassisted high-pressure, high-resolution separations with intelligent selection and multiplexing coupled to selected reaction monitoring), for enabling proteomic analysis of low numbers of cells. ${ }^{41}$ For cPRISM-SRM, we used bovine serum albumin (BSA) $(\sim 50 \mu \mathrm{g})$ as a carrier to minimize losses in conjunction with highly sensitive PRISM-SRM and found that we could detect low-abundance proteins in as few as 100 mammalian cells as well as 
high- to moderate-abundance proteins in single mammalian cell equivalents. This is $\sim 3-4$ orders of magnitude lower than the cell number required for current targeted MS methods (typically $\sim 10^{5}-10^{6}$ cells). ${ }^{42,43}$ However, a key drawback of cPRISM-SRM is its moderate sample throughput because of the need of high-resolution PRISM to reduce the increased dynamic concentration range originating from the addition of the carrier protein.

In this work we have developed an alternative simple and effective targeted proteomics approach, termed cLC-SRM (carrier-assisted liquid chromatography coupled to selected reaction monitoring) that removes the need for extensive sample fractionation, yet is suitable for the multiplexed quantification of proteins from very low numbers of mammalian cells. cLC-SRM utilizes (1) full processing of small numbers of cells in a single tube, (2) low amounts of BSA protein and high amounts of trypsin as an effective carrier combined with tube pretreatment to minimize sample loss, and (3) highly sensitive SRM for protein quantification. cLC-SRM was demonstrated to enable multiplexed detection of target proteins expressed at $\geq 30000$ copies per cell in 10 MCF7 cells and at $\geq 3000$ copies per cell (e.g., SOS1) in 100 MCF7 cells.

\section{EXPERIMENTAL SECTION}

\section{Reagents.}

Tetrafluoroethylene (TFE), dithiothreitol (DTT), iodoacetamide (IAA), ammonium bicarbonate, formic acid, and BSA were obtained from Sigma-Aldrich (St. Louis, MO). Affymetrix/USB trypsin enzyme was purchased from Thermo Fisher Scientific (Rockford, IL). Synthetic crude heavy peptides labeled with ${ }^{13} \mathrm{C} /{ }^{15} \mathrm{~N}$ on the C-terminal arginine or lysine and pure light peptides with $>95 \%$ purity were purchased from Thermo Fisher Scientific (San Jose, CA).

\section{Cell Culture.}

The MCF7 breast cancer cell line was obtained from the American Type Culture Collection (Manassas, VA) and was grown as previously described. ${ }^{44}$ Briefly, MCF7 cells were maintained in $15 \mathrm{~cm}$ dishes in ATCC-formulated Eagle's minimum essential medium (Thermo Fisher Scientific) supplemented with $0.01 \mathrm{mg} / \mathrm{mL}$ human recombinant insulin and a final concentration of $10 \%$ fetal bovine serum (Thermo Fisher Scientific) and $1 \%$ penicillin/streptomycin (Thermo Fisher Scientific). Cells were grown at $37{ }^{\circ} \mathrm{C}$ with $95 \% \mathrm{O}_{2}$ and $5 \% \mathrm{CO}_{2}$. Cells were seeded into $15 \mathrm{~cm}$ culture plates and grown until near confluence.

\section{MCF7 Cell Lysates.}

MCF7 cells were rinsed twice with ice-cold PBS and harvested in $1 \mathrm{~mL}$ of ice-cold PBS containing 1\% phosphatase inhibitor cocktail (Pierce, Rockford, IL) and $10 \mathrm{mM} \mathrm{NaF}$ (Sigma-Aldrich, St. Louis, MO). Cells were centrifuged at $1500 \mathrm{rpm}$ for $10 \mathrm{~min}$ at $4{ }^{\circ} \mathrm{C}$, and excess PBS was carefully aspirated from cell pellet. Cell pellets were resuspended in icecold cell lysis buffer (250 mM HEPES, $8 \mathrm{M}$ urea, $150 \mathrm{mM} \mathrm{NaCl}, 1 \%$ Triton X-100, pH 6.0) at a ratio of $\sim 3: 1$ lysis buffer to cell pellet. Cell lysates were centrifuged at $14000 \mathrm{rpm}$ at $4{ }^{\circ} \mathrm{C}$ for $10 \mathrm{~min}$, and soluble protein fraction was retained. Protein concentrations were determined by the BCA assay (Pierce, Rockford, IL). 


\section{RT-PCR Tube Pretreatment.}

Reverse transcription polymerase chain reaction (RT-PCR) tubes (GeneMte) with $0.2 \mathrm{~mL}$ of volume were coated with Shewanella oneidensis lysate digests. The selection of cell lysate digests rather than cell lysates or standard proteins for coating the tube is because the absorption amount of proteins on the tube surface is hard to determine and the large amount absorption may have severe effects on sample digestion and SRM detection. The tubes were pretreated by the addition of $100 \mu \mathrm{L}$ of S. oneidensis digests at a concentration of $0.2 \mu \mathrm{g} / \mu \mathrm{L}$ with incubation for overnight at room temperature. The pretreatment solution was removed, and the RT-PCR tube was rinsed three times with HPLC-grade water, and then air-dried in the fume hood. The dried RT-PCR tube was stored until further use. The coated nonmammalian peptides may fall off from the RT-PCR tube wall but should not affect SRMbased targeted quantification of mammalian peptides in terms of sensitivity and accuracy.

\section{MCF7 Cell Equivalents for Optimization of Trypsin Amount and Denaturing Temperature.}

A stock of $1 \mu \mathrm{g} / \mu \mathrm{L}$ of bulk MCF7 cell lysate was diluted to $10 \mathrm{ng} / \mu \mathrm{L}$ (equivalent to $\sim 100$ cells $/ \mu \mathrm{L}$ ) with $\sim 10 \mathrm{ng} /, \mu \mathrm{L} \mathrm{BSA}$ in $25 \mathrm{mM} \mathrm{NH}_{4} \mathrm{HCO}_{3}$. An amount of $1 \mu \mathrm{L}$ of $10 \mathrm{ng} / \mu \mathrm{L}$ MCF7 cell lysates was added to the $S$. oneidensis-coated RT-PCR tube with the addition of $100 \mathrm{fmol}$ of crude heavy peptide standards to optimize the single-tube TFE digestion method. To evaluate the impact of trypsin concentration on digestion efficiency, $10 \mathrm{ng}$ of MCF7 cell lysates was digested at different trypsin concentrations $(1,2.5,5,10,15,20 \mathrm{ng} /$ $\mu \mathrm{L}$ ) with two processing replicates per each concentration. Furthermore, $10 \mathrm{ng}$ MCF7 cell lysates were also used to evaluate digestion efficiency for three different denaturing temperatures $\left(60^{\circ} \mathrm{C}, 75^{\circ} \mathrm{C}, 90^{\circ} \mathrm{C}\right)$ with two processing replicates per each temperature.

\section{MCF7 Cell Equivalents for Evaluation of Platform Performance.}

A stock of $1 \mu \mathrm{g} / \mu \mathrm{L}$ of bulk MCF7 cell lysates was diluted to different protein concentrations $(0.5,1,2,5,10,20 \mathrm{ng} / \mu \mathrm{L}$ equivalent to $5,10,20,50,100,200$ cells $/ \mu \mathrm{L})$ with $\sim 10 \mathrm{ng} / \mu \mathrm{L}$ BSA in $25 \mathrm{mM} \mathrm{NH}_{4} \mathrm{HCO}_{3}$. The sample dilution was performed in the $S$. oneidensis-coated RT-PCR tubes. From each point, $1 \mu \mathrm{L}$ was transferred to the new $S$. oneidensis-coated RTPCR tube with the addition of $30 \mathrm{fmol}$ of crude heavy peptide standards. To evaluate the processing reproducibility, three processing replicates were performed with each containing $5 \mathrm{ng}$ of MCF7 cell lysates (equivalent to 50 cells) and $30 \mathrm{fmol}$ of crude peptide standards.

\section{Intact MCF7 Cells Isolated by Fluorescence-Activated Cell Sorting (FACS).}

The cultured MCF7 cells were washed with PBS for one time and detached using $0.25 \%$ trypsin (Gibco, Grand Island, NY). To avoid cell clumping, after detaching they were dispersed into a single-cell suspension by passing three times through a 25 gauge needle. The cells were suspended in PBS, and then pelleted by centrifuging $5 \mathrm{~min}$ at $500 \mathrm{~g}$. This process was repeated for five times to remove the remaining PBS and trypsin. After that the cells were resuspended in PBS and passed through a $35 \mu \mathrm{m}$ mesh cap (BD Biosciences, Canaan, CT) to remove large aggregates. A BD Influx flow cytometer (BD Biosciences, San Jose, CA) was used to deposit cells into the precoated RT-PCR tubes. Alignment into a Hard-Shell 96-well PCR plate (Bio-Rad, Hercules, CA) was done using fluorescent beads (Spherotech, Lake Forest, IL) after which the coated RT-PCR tubes are placed into the plates 
for cell collection. For unstained MCF7 cells, forward and side scatter detectors were used for cell identification. Once sorting gates were established, cells were sorted into the RTPCR tubes using the 1-drop single sort mode. After isolation of the desired number of cells into the RT-PCR tube, the isolated cells were immediately centrifuged at $1000 \mathrm{~g}$ for $10 \mathrm{~min}$ at $4{ }^{\circ} \mathrm{C}$ to keep the cells at the bottom of the tube to avoid potential cell loss. The RT-PCR tubes with the isolated cells were stored in a $-80{ }^{\circ} \mathrm{C}$ freezer until further analysis.

\section{Optimized Single-Tube TFE Digestion Protocol.}

For MCF7 cell lysates, starting with $1 \mu \mathrm{g} / \mu \mathrm{L}$ stock, different concentrations were generated by serial dilution with $10 \mathrm{ng} / \mu \mathrm{L}$ BSA in $25 \mathrm{mM} \mathrm{NH}_{4} \mathrm{HCO}_{3}$. A pipette at the volume range of $0.2-2 \mu \mathrm{L}$ was used to accurately deliver the desired low volume smaller than $2 \mu \mathrm{L}$ with pipetting up and down for three times. First, $1 \mu \mathrm{L}$ of MCF7 cell lysates at the desired concentration was added to the coated RT-PCR tube together with $4 \mu \mathrm{L}$ of $25 \mathrm{mM}$ $\mathrm{NH}_{4} \mathrm{HCO}_{3}$ and $0.3 \mu \mathrm{L}$ of $100 \mathrm{fmol} / \mu \mathrm{L}$ heavy peptide standards with centrifugation at 5000 rpm for $3 \mathrm{~min}$. Amounts of $9 \mu \mathrm{L}$ of $100 \%$ TFE and $0.6 \mu \mathrm{L}$ of $50 \mathrm{mM}$ DTT were then added with a final $60 \%$ TFE and $2 \mathrm{mM}$ DTT. Samples were centrifuged at $5000 \mathrm{rpm}$ for $5 \mathrm{~min}$, and then gently mixed at $850 \mathrm{rpm}$ for $3 \mathrm{~min}$. The sample were then incubated at $90^{\circ} \mathrm{C}$ for $1 \mathrm{~h}$ for protein denaturation using the RT-PCR thermocycler (Thermo Fisher Scientific) with the heated lid option followed by cooling to room temperature with centrifugation at $5000 \mathrm{rpm}$ for $3 \mathrm{~min}$. A total of $0.5 \mu \mathrm{L}$ of $60 \mathrm{mM}$ IAA was added to the RT-PCR tube for a final concentration of $\sim 2 \mathrm{mM}$. The sample was then incubated in the dark at room temperature for $30 \mathrm{~min}$ with gentle shaking at $850 \mathrm{rpm}$. Prior to the addition of trypsin, the sample was concentrated to a volume of $\sim 4 \mu \mathrm{L}$ to reduce TFE volume for digestion using a SpeedVac concentrator. An amount of $9 \mu \mathrm{L}$ of $25 \mathrm{mM} \mathrm{NH}_{4} \mathrm{HCO}_{3}$ was then added together with 2.25 $\mu \mathrm{L}$ of $100 \mathrm{ng} / \mu \mathrm{L}$ USB trypsin for a final concentration of $\sim 15 \mathrm{ng} / \mu \mathrm{L}$. The sample was gently mixed at $850 \mathrm{rpm}$ for $3 \mathrm{~min}$, and then incubated for overnight $(\sim 16 \mathrm{~h})$ at $37{ }^{\circ} \mathrm{C}$ for digestion. After trypsin digestion $0.5 \mu \mathrm{L}$ of $5 \%$ FA was added to stop the enzymatic reaction. The final sample was centrifuged at $14000 \mathrm{~g}$ for $1 \mathrm{~h}$.

For FACS-isolated intact MCF7 cells, the only change was the first step in which $4 \mu \mathrm{L}$ of 25 $\mathrm{mM} \mathrm{NH} \mathrm{HCO}_{3}, 1 \mu \mathrm{L}$ of $10 \mathrm{ng} / \mu \mathrm{L}$ BSA in $25 \mathrm{mM} \mathrm{NH}_{4} \mathrm{HCO}_{3}$, and $0.3 \mu \mathrm{L}$ of $100 \mathrm{fmol} / \mu \mathrm{L}$ crude heavy peptide standards (total $30 \mathrm{fmol}$ ) were added to the sample tube. Amounts of 9 $\mu \mathrm{L}$ of $100 \%$ TFE and $0.6 \mu \mathrm{L}$ of $50 \mathrm{mM}$ DTT were then added with the final $60 \%$ TFE and 2 $\mathrm{mM}$ DTT. The sample was centrifuged at $5000 \mathrm{rpm}$ for $5 \mathrm{~min}$, and then gently mixed at 850 rpm for $3 \mathrm{~min}$. The sample was sonicated for $1 \mathrm{~min}$, and then placed on ice for $1 \mathrm{~min}$ for a total of five cycles.

\section{LC-SRM Analysis.}

The selection of surrogate peptides for epidermal growth factor receptor (EGFR) pathway proteins and the SRM assays were described previously. ${ }^{42,45}$ SRM assays for EGFR pathway proteins and the transitions selected are summarized in Tables S1 and S2. Highpurity light peptides ( $>95 \%$ ) were used to calibrate crude heavy peptide concentrations. The determined copy numbers per cell for EGFR pathway proteins across different human cell lines are listed in Table S3. 
Samples were analyzed using a nanoACQUITY UPLC (Waters Corporation, Milford, MA) coupled to a TSQ Vantage triple quadrupole mass spectrometer (Thermo Scientific, San Jose, CA). The UPLC's nanoACQUITY UPLC BEH $1.7 \mu \mathrm{m}$ C18 column $(75 \mu \mathrm{m}$ i.d. $\times 20$ $\mathrm{cm}$ ) was connected to a chemically etched $20 \mu \mathrm{m}$ i.d. fused-silica electrospray emitter via a stainless metal union. Solvents used were $0.1 \%$ formic acid in water (mobile phase A) and $0.1 \%$ formic acid in $90 \%$ acetonitrile (mobile phase B). An amount of $\sim 4 \mu \mathrm{L}$ out of the total $\sim 15 \mu \mathrm{L}$ peptide sample was directly loaded onto the BEH C18 column from the RT-PCR tube without using a trapping column. Sample loading and separation were performed at a flow rate of 350 and $300 \mathrm{~nL} / \mathrm{min}$, respectively. The binary LC gradient was used: 5-20\% B in $26 \mathrm{~min}, 20-25 \% \mathrm{~B}$ in $10 \mathrm{~min}, 25-40 \% \mathrm{~B}$ in $8 \mathrm{~min}, 40-95 \% \mathrm{~B}$ in $1 \mathrm{~min}$ and at $95 \%$ B for 7 min for a total of $52 \mathrm{~min}$, and the analytical column was re-equilibrated at $99.5 \% \mathrm{~A}$ for 8 $\mathrm{min}$. The TSQ Vantage mass spectrometer was operated with ion spray voltages of 2400 $\pm 100 \mathrm{~V}$, a capillary offset voltage of $35 \mathrm{~V}$, a skimmer offset voltage of $-5 \mathrm{~V}$, and a capillary inlet temperature of $220^{\circ} \mathrm{C}$. The tube lens voltages were obtained from automatic tuning and calibration without further optimization. The retention time scheduled SRM mode was applied for SRM data collection with the scan window of $\succ 6 \mathrm{~min}$. The cycle time was set to $1 \mathrm{~s}$, and the dwell time for each transition was automatically adjusted depending on the number of transitions scanned at different retention time windows. A minimal dwell time 10 ms was used for each SRM transition. All the EGFR pathway proteins were simultaneously monitored in a single LC-SRM analysis.

\section{Data Analysis.}

Skyline software was used for all SRM data analysis. ${ }^{46}$ The raw data were initially imported into Skyline software for visualization of chromatograms of target peptides to determine the detectability of target peptides. For each peptide the best transition without matrix interference was used for precise quantification. Two criteria were used to determine the peak detection and integration: (1) same retention time and (2) approximately the same relative SRM peak intensity ratios across multiple transitions between endogenous (light) peptide and heavy peptide internal standards. Standard derivation (SD) and coefficient of variation $(\mathrm{CV})$ were obtained from multiple technical or biological replicates. All the data were manually inspected to ensure correct peak detection and accurate integration. The signal-to-noise ratio $(\mathrm{S} / \mathrm{N})$ was calculated by the peak apex intensity over the highest background noise within a retention time region of $\pm 15 \mathrm{~s}$ for the target peptide. The limit of detection (LOD) and the limit of quantification (LOQ) were defined as the lowest concentration points of each target protein at which the $\mathrm{S} / \mathrm{N}$ ratio of surrogate peptides was at least 3 and 7, respectively. For conservatively determining the LOQ values, in addition to the requirement of $S / N \geq 7$, one additional criteria was applied: surrogate peptide response over different cell numbers must be within the linear dynamic range. All calibration curves were plotted using Microsoft Excel 2007. The RAW data from TSQ Vantage were loaded into Skyline software to display graphs of extracted ion chromatograms (XICs) of multiple transitions of target proteins monitored. 


\section{RESULTS}

Effective sample processing is one of the major bottlenecks for the MS-based proteomics analysis of low amounts of proteins. To address this issue we have developed a carrierassisted single-tube TFE digestion method for effective processing of small numbers of cells with minimal sample loss followed by sensitive LC-SRM analysis, termed CLC-SRM (Figure 1A). Prior to cell collection, the RT-PCR tube was pretreated with $S$. oneidensis lysate digests to reduce surface absorption. An amount of $10 \mathrm{ng}$ of BSA (equivalent to 100 mammalian cells in protein mass) was then added to the coated RT-PCR tube to further prevent adsorption loss, especially when using few cells (e.g., $\unlhd 0$ cells). The BSA amount was determined by evaluation of BSA peptide abundance and hydrophobicity distribution across the LC elution profile from tryptic digestion of different amounts of BSA (i.e., 10, 50, $500 \mathrm{ng}$ ). Full MS scan analysis indicated that $10 \mathrm{ng}$ of BSA digest generates sufficient peptide peaks across the entire LC profile without potential severe ion suppression (Figure S1). The TFE digestion method was selected because it has been routinely used for digestion of low microgram amounts of proteins. ${ }^{47,48}$ Importantly, it can be performed in a single tube without the need of sample transfer and cleanup to avoid undesired sample loss. EGFR pathway proteins were selected for targeted quantification due to the availability of heavy peptide internal standards with established SRM assays (Tables S1 and S2), as well as the known protein copy number per cell from our recent study (Table S3). ${ }^{43}$ We thus extensively optimized the single-tube TFE digestion method for effective processing of small numbers of mammalian cells. Denaturing temperature and trypsin amount were found to be two key parameters that most affected digestion efficiency of low protein amounts, whereas the other parameters (e.g., the TFE volume and the concentrations of reducing and alkylation reagents) had negligible effects.

\section{Optimization of Protein Digestion.}

Starting with the standard TFE digestion protocol and using a ratio of trypsin to protein (w/w) of 1:50, $10 \mathrm{ng}$ of MCF7 cell lysates was processed and digested in the coated RT-PCR tube with minimal sample dilution (total volume of $\sim 15 \mu \mathrm{L}$ ) (Figure 1B). Following LCSRM analysis, no SRM signal was detected, even for the most abundant PEBP1 protein. We attributed this to the very low enzyme and protein concentrations $(\sim 13 \mathrm{pg} / \mu \mathrm{L}$ for trypsin and $\sim 667 \mathrm{pg} / \mu \mathrm{L}$ protein), which would result in a relatively low digestion efficiency as compared to standard solution digestion protocols ( $\geq 10 \mathrm{ng} / \mu \mathrm{L}$ for trypsin and $\geq 1 \mu \mathrm{g} / \mu \mathrm{L}$ protein). ${ }^{49,50}$ Because of the limited protein concentrations that can be obtained from small numbers of mammalian cells, we felt it necessary to compensate by significantly increasing the trypsin concentration.

A series of trypsin concentrations at $1-20 \mathrm{ng} / \mu \mathrm{L}$ were evaluated using $10 \mathrm{ng}$ of MCF7 cell lysates. Four surrogate peptides derived from three high-abundance proteins were measured by LC-SRM (Table S4A). As trypsin concentrations increased from 1 to $10 \mathrm{ng} / \mu \mathrm{L}$, the abundance of all endogenous peptides (i.e., the $\mathrm{L} / \mathrm{H}$ peak area ratio) increased significantly by at least 6 -fold. Increasing trypsin concentration beyond $15 \mathrm{ng} / \mu \mathrm{L}$ produced variable results and no further significant increase in $\mathrm{L} / \mathrm{H}$ ratio for any of the tested peptides (Figure $2 \mathrm{~A})$. Therefore, trypsin concentration at $15 \mathrm{ng} / \mu \mathrm{L}$ was selected for the single-tube TFE 
digestion method. The decreased abundance for peptide LVVVGAGGVGK at $20 \mathrm{ng} / \mu \mathrm{L}$ suggested that ion suppression was occurring, which was supported by global proteomics analysis (Figure S2). Global profiling of $10 \mathrm{ng}$ of MCF7 cell lysate digests at different trypsin concentrations showed that a majority of the highly abundant peptides originated from trypsin autodigestion (Figure S2A). Importantly, elevated trypsin levels also appeared to act as an effective carrier to reduce absorption loss at both the protein and peptide levels because of the total amount of trypsin and its corresponding peptides. When compared to 10 $\mathrm{ng}$ of BSA carrier, the total amount of trypsin was $\sim 225 \mathrm{ng}$ (i.e., $\sim 15 \mathrm{ng} / \mu \mathrm{L}$ with a total sample volume of $\sim 15 \mu \mathrm{L}$ ).

\section{Optimizing Denaturing Temperature.}

Another important factor to affect digestion efficiency is protein denaturation. For standard TFE digestion protocols, proteins are incubated at $60{ }^{\circ} \mathrm{C} .47,48$ However, $60{ }^{\circ} \mathrm{C}$ did not appear to be adequate for denaturing the low amounts of proteins in our samples (Figure 2B). In an attempt to further improve trypsin digestion efficiency, three denaturing temperatures $\left(60{ }^{\circ} \mathrm{C}, 75^{\circ} \mathrm{C}, 90^{\circ} \mathrm{C}\right)$ were evaluated at a trypsin concentration of $15 \mathrm{ng} / \mu \mathrm{L}$. Protein denaturation was performed in a PCR thermocycler with a heated lid option. Comparative analysis of the $\mathrm{L} / \mathrm{H}$ area ratios for the three temperatures showed that increasing denaturing temperature improved the digestion efficiency (Figure 2B). When compared to the standard $60{ }^{\circ} \mathrm{C}, 90^{\circ} \mathrm{C}$ improved $\mathrm{L} / \mathrm{H}$ area ratios by at least 7 -fold. Thus, $90{ }^{\circ} \mathrm{C}$ was selected as the optimal denaturing temperature.

\section{Sensitivity and Reproducibility of cLC-SRM.}

The performance of cLC-SRM on small amounts of cell lysates was evaluated by targeted quantification of 10 EGFR pathway proteins spanning a wide dynamic concentration range (Table S4B). We used pooled MCF7 cell lysates to eliminate variations due to stochastic sampling of small numbers of intact cells. Different amounts of MCF7 cell lysates with 0.5$20 \mathrm{ng}$ of total proteins (equivalent to 5-200 cells) were processed with the optimized singletube TFE digestion method followed by LC-SRM analysis. Multiple SRM technical replicates were performed for each data point (i.e., three replicates for $0-1 \mathrm{ng}$ and two replicates for 2-20 ng) (Table S5). The obtained LODs and LOQs were used to evaluate the detection sensitivity. As shown in Figure 3A, XICs clearly shows transitions for ATADDELSFK derived from GRB2 present at 220000 copies per MCF7 cell. cLC-SRM was able to reproducibly quantify endogenous ATADDELSFK down to five MCF7 cell equivalents with an $\mathrm{S} / \mathrm{N}$ ratio of 14 and $\sim 1800 \mathrm{zmol}$ of quantification sensitivity (Table 1 and Table S6). Furthermore, moderate-abundance PTPN11 at $~ 54000$ copies per cell was detected in 10 cell equivalents with an $\mathrm{S} / \mathrm{N}$ ratio of 6 and $\sim 900 \mathrm{zmol}$ of detection sensitivity (Table 1 and Table S6). Sensitivity was further confirmed by confident detection of multiple endogenous peptides from other low-abundance EGFR pathway proteins in $20 \mathrm{MCF} 7$ cell equivalents (e.g., FYGAEIVSALDYLHSEK derived from AKT1 at 4000 copies per cell with S/N ratio of 5 and $\sim 120$ zmol of detection sensitivity, and SFEDLTDHPVTR derived from ADAM17 at $\sim 10000$ copies per cell with S/N ratio of 3 and $\sim 300$ zmol of detection sensitivity) (Table 1 and Table S6). The resultant calibration curves displayed excellent linearity over a wide dynamic range of MCF7 cell equivalents (Figure 3, parts B and C, and Figures S3-S11) with LOQs of $\sim 5-10$ cells for high-abundance proteins, $\sim 10-20$ cells for 
moderate-abundance proteins, and 50-200 cells for low-abundance proteins (Table 1). All these results suggest that cLC-SRM can provide $\sim 100-4000 \mathrm{zmol}$ of detection sensitivity and $\sim 300-7000 \mathrm{zmol}$ of quantification sensitivity.

The median SRM technical CV for all target peptides across all the data points was 9\% (Table S5), consistent with the technical reproducibility of well-characterized LC-SRM with CV below $10 \% .{ }^{42,45,51-54}$ The overall reproducibility of cLC-SRM was evaluated by targeted analysis of three processing replicates for 12 surrogate peptides derived from lowto high-abundance EGFR pathway proteins in 50 MCF7 cell equivalents (Table S7). The processing CVs ranged from $1.4 \%$ to $28.7 \%$ with the median value of $11.8 \%$, suggesting high processing reproducibility of cLC-SRM. As expected, low- and moderate-abundance proteins have higher CVs than high-abundance proteins, which can be largely attributed to variations in SRM detection sensitivity.

\section{Quantification of EGFR Pathway Proteins in FACS-Isolated MCF7 Cells.}

With the demonstration of technique robustness using cell lysates, we next applied cLCSRM to measure EGFR pathway proteins in 10 and 100 intact MCF7 cells isolated by FACS. Using our previously established SRM assays ${ }^{43}$ (Tables S1 and S2), 32 core EGFR pathway proteins and feedback regulators with a wide dynamic concentration range (Table S3) were measured using 10 and 100 intact MCF7 cells with two biological replicates per each to evaluate practical applicability. Three technical replicates per biological replicate were performed to evaluate the overall performance of cLC-SRM for quantitative analysis of intact cells (Table S8). cLC-SRM enabled detection of high- and moderate-abundance proteins in 10 intact MCF7 cells with the median CV of 13.5\% (Figures 4 and S12, and Tables 2 and S8). Even low-abundance AKT1 at $\sim 3700$ copies per cell was also detected with the average S/N ratio of 7 (Table S9), consistent with cLC-SRM measurements of MCF7 cell lysates (Figure S11). When the cell number was increased to 100, the endogenous SRM signal of AKT1 peptide was increased accordingly with the average S/N ratio of 28 (Table S9). A majority of previously identified important EGFR pathway proteins ( 22 out of the total 32 proteins) ${ }^{43}$ were reliably detected and quantified by CLC-SRM with the median $\mathrm{CV}$ of $12.7 \%$, with the exception of extremely low-abundance negative feedback regulators and known low-expression EGFR protein in MCF7 cells (Figure S12 and Table 2). These results suggests that CLC-SRM can be used to study signaling pathways in small numbers of mammalian cells. Significantly, the endogenous peptide from low-abundance SOS1, present at only $\sim 3000$ copies per cell, was detected in 100 MCF7 cells with the average $\mathrm{S} / \mathrm{N}$ ratio of 9 (Table S9), suggesting $\sim 500 \mathrm{zmol}$ of absolute sensitivity of cLCSRM. This further confirms that cLC-SRM can provide $~ 100-1000 \mathrm{zmol}$ of detection sensitivity. We also note that the detectability of endogenous peptides shows a strong positive correlation with the total number of protein molecules (Tables 2 and S8).

\section{DISCUSSION}

We have recently demonstrated that the addition of exogenous carrier proteins allows small numbers of mammalian cells to be effectively processed using conventional sample preparation protocols with minimal sample loss. ${ }^{41}$ However, our previous approach required 
high-resolution PRISM to reduce the increased sample dynamic concentration range resulting from the addition of large amounts of carrier protein, thus generating many fraction samples that significantly lowered sample throughput. To alleviate this problem, we have developed a carrier-assisted LC-SRM approach for precise multiplexed analysis of small numbers of mammalian cells. When compared to cPRISM-SRM, cLC-SRM has 3-5-fold lower sensitivity for protein quantification. ${ }^{41}$ cLC-SRM capitalizes on using optimized single-tube TFE digestion and a combination of low amounts of carrier protein and high trypsin concentration for effectively processing small numbers of cells while retaining the ability to perform sensitive SRM for protein quantification.

The optimized TFE digestion method was demonstrated to effectively prevent sample losses at both the protein and peptide levels (Figure 1). First, it utilizes relatively small volumes $(\sim 15 \mu \mathrm{L})$ without sample transfer and cleanup to avoid sample loss. Second, to significantly reduce surface absorption, the $S$. oneidensis-coated RT-PCR tubes were used together with small amounts of BSA (i.e., $10 \mathrm{ng})$ and relatively high amounts of trypsin ( 225 ng). The digested BSA and trypsin peptides as well as heavy peptide standards help prevent sample loss at the peptide level (e.g., peptide losses during LC separation). Importantly, high concentrations of trypsin increased protein digestion efficiency when small numbers of cells were used. Formation of the enzymatic digestion complex is very rapid with the rate constant $K\left(K=\right.$ [enzyme-protein]/[enzyme][protein]) being the limiting factor. ${ }^{55}$ Thus, digestion efficiency is primarily determined by protein and enzyme concentrations. For small numbers of mammalian cells (e.g., 100 cells equivalent to $10 \mathrm{ng}$ ) processed in a volume of $\sim 15 \mu \mathrm{L}$, the protein concentration is less than $1 \mathrm{ng} / \mu \mathrm{L}$, which is $\sim 1000$-fold lower than typical for bulk cell digestion $(\sim 1 \mu \mathrm{g} / \mu \mathrm{L}) \cdot{ }^{49,50,56}$ Thus, significantly increasing trypsin concentrations is required for rapid and efficient digestion. Our optimized TFE digestion protocol has a trypsin to protein ratio of $\sim 20: 1$ (w/w), which is $\sim 1000$-fold higher than standard trypsin digestion protocols (i.e., $\sim 1: 50) .{ }^{42,57-59}$ This trypsin concentration significantly improved digestion efficiency with negligible effects on targeted MS quantification. However, we did observe that the increased trypsin amount had a disproportionate effect on data-dependent acquisition-based global proteomics profiling because the highly abundant trypsin and BSA peptides are much more likely to be selected for MS/MS sequencing (Figure S2). Thus, global proteomics measurements do not benefit from the high trypsin concentration used here for targeted proteomics. Protein denaturing temperature was also found to be another important factor affecting digestion efficiency. Because TFE is a volatile solvent with boiling point of $74{ }^{\circ} \mathrm{C}$, at the optimal denaturing temperature $\left(90^{\circ} \mathrm{C}\right)$ a PCR thermocycler rather than other heating devices ${ }^{50}$ (e.g., the Eppendorf thermomixer) was used to maintain a good cap seal so as to avoid TFE loss. In addition, prior to the addition of trypsin, it was necessary to reduce the TFE levels to $₫ 0 \%$ for effective trypsin digestion. To avoid drying out samples with unrecoverable loss, it was necessary to frequently check the sample volume ( $\sim \mu \mathrm{L}$ of the remaining volume) during SpeedVac concentrating.

In terms of overall analytical performance, cLC-SRM was found to provide high sensitivity, reproducibility, and good multiplexing capability. The median $\mathrm{CV}$ for processing small numbers of cells, including sample preparation, was $11.8 \%$, which is consistent with that of $\sim 10 \%$ obtained by LC-SRM in technical replicates. ${ }^{42,45}$ With peptide retention time 
scheduling and the use of advanced triple quadrupole mass spectrometers, cLC-SRM should enable simultaneous quantification of up to 1000 target peptides (i.e., 500 proteins assuming that each protein has two surrogate peptides) in a single LC-SRM analysis.

Using standard LC-MS instruments, cLC-SRM was demonstrated to enable detection of most moderate-abundance proteins at $\sim 30000$ copies per cell in 10 MCF7 cells and even lower abundance proteins (e.g., SOS1 at $\sim 3000$ copies per cell) in 100 MCF7 cells (Figure S12 and Table S8). The previously reported low-abundance AKT1 could also be detected and quantified in 10 MCF7 cells. Furthermore, unlike immunoassays that require significant amounts of development time and rely on the availability of high-quality antibodies, ${ }^{13,15}$ cLC-SRM is relatively easy to implement with commercially available platforms, and should be useful for precise quantification of important proteins in small subpopulations of cells (e.g., fine-needle aspirants from minimally invasive biopsies) that cannot be readily accessed by targeted antibody-based immunoassays.

We note that cLC-SRM still cannot provide sufficient sensitivity to detect and quantify the majority of proteins in a single mammalian cell. Significantly enhancing the detection sensitivity of cLC-SRM is necessary for moving toward targeted single-cell proteomics. The LC-MS sensitivity increases almost linearly with decreasing the LC flow rate, and is thus inversely proportional to the square of the LC column inner diameter. ${ }^{60,61}$ When compared to ultrasensitive LC-MS platforms (1-10 zmol sensitivity with an ultralow flow rate of 10 $20 \mathrm{~nL} / \mathrm{min}),{ }^{22,25}$ current cLC-SRM uses the standard nanoLC flow rate of $\sim 300 \mathrm{~nL} / \mathrm{min}$ with 100-1000 zmol sensitivity. Therefore, further enhancing the detection sensitivity of cLC-SRM could be achieved by implementation of ultralow-flow capillary electrophoresis ${ }^{24,25}$ or LC ${ }^{22,23}$ with maintaining similar separation efficiency when integrated with a high-efficiency ion source and ion transmission interface. ${ }^{62,63}$ In addition, in our current LC-MS settings, the maximum loading volume is $\sim 4 \mathrm{~L}$ with a $5 \mu \mathrm{L}$ loop, and only approximately one-third of the total amount of samples was used for LC-SRM analysis. Our next step is to replace the current $5 \mu \mathrm{L}$ loop with $20 \mu \mathrm{L}$ loop for loading nearly all the samples to the LC column. We anticipate that $>10$-fold improvement in sensitivity can be achieved ( $>5$-fold from the ultralow-flow separation and $\sim 2$-fold from the full loop loading), which may allow cLC-SRM for quantification of proteins at 230000 copies per cell in a single mammalian cell. Such levels of improvement could enable quantifying $35 \%$ human proteome in a single mammalian cell (i.e., $\sim 5200$ out of $\sim 15000$ proteins in a single HeLa cell). ${ }^{27}$

\section{CONCLUSION}

We have developed a simple carrier-assisted targeted proteomics approach for enabling effective sample processing and multiplexed quantification of proteins in very low numbers of mammalian cells. Using a standard LC-MS platform it can reproducibly detect target proteins at $\geq 30000$ and $>3000$ copies per cell in 10 and 100 mammalian cells, respectively. Such sensitivity is sufficient for quantification of the majority of important pathway proteins in small subpopulations of cells or mass-limited clinical specimens. Furthermore, this method can be easily implemented in any MS and proteomics laboratories at no additional 
cost for instrument or reagents. We anticipate that it can be broadly applied to biomedical research and systems biology with the potential of facilitating precision medicine.

\section{Supplementary Material}

Refer to Web version on PubMed Central for supplementary material.

\section{ACKNOWLEDGMENTS}

Portions of the research were supported by NIH Grants R21CA223715, P41GM103493, and NCI EDRN Interagency Agreement ACN15006-001. Dr. Pengfei Zhang acknowledges the fellowship support from China Scholarship Council. The experimental work described herein was performed in the Environmental Molecular Sciences Laboratory, Pacific Northwest National Laboratory, a national scientific user facility sponsored by the United States of America Department of Energy under contract DE-AC05-76RL0 1830.

\section{REFERENCES}

(1). Altschuler SJ; Wu LF Cell 2010, 141, 559-563. [PubMed: 20478246]

(2). Bateman NW; Conrads TP J. Pathol 2018, 244, 628-637. [PubMed: 29344964]

(3). Hughes AJ; Spelke DP; Xu ZC; Kang CC; Schaffer DV; Herr AE Nat. Methods 2014, 11, 749_ 755. [PubMed: 24880876]

(4). Wang D; Bodovitz S Trends Biotechnol 2010, 28, 281-290. [PubMed: 20434785]

(5). Gavasso S; Gullaksen SE; Skavland J; Gjertsen BT Expert Rev. Mol. Diagn 2016, 16, 579-589. [PubMed: 26895397]

(6). Macaulay IC; Ponting CP; Voet T Trends Genet. 2017, 33, 155-168. [PubMed: 28089370]

(7). Seoane J; De Mattos-Arruda LJ Intern. Med 2014, 276, 41-51.

(8). Sundaresan TK; Haber DA Lancet Oncol. 2015, 16, 1596-1598. [PubMed: 26678190]

(9). Yu M; Bardia A; Wittner BS; Stott SL; Smas ME; Ting DT; Isakoff SJ; Ciciliano JC; Wells MN; Shah AM; Concannon KF; Donaldson MC; Sequist LV; Brachtel E; Sgroi D; Baselga J; Ramaswamy S; Toner M; Haber DA; Maheswaran S Science 2013, 339, 580-584. [PubMed: 23372014]

(10). Wang Y; Navin NE Mol. Cell 2015, 58, 598-609. [PubMed: 26000845]

(11). Wang Z; Gerstein M; Snyder M Nat. Rev. Genet 2009, 10, 57-63. [PubMed: 19015660]

(12). Peterson VM; Zhang KX; Kumar N; Wong J; Li L; Wilson DC; Moore R; McClanahan TK; Sadekova S; Klappenbach JA Nat. Biotechnol 2017, 35, 936-939. [PubMed: 28854175]

(13). Spitzer MH; Nolan GP Cell 2016, 165, 780-791. [PubMed: 27153492]

(14). Wu M; Singh AK Curr. Opin. Biotechnol 2012, 23, 83-88. [PubMed: 22189001]

(15). Bendall SC; Nolan GP; Roederer M; Chattopadhyay PK Trends Immunol. 2012, 33, 323-332. [PubMed: 22476049]

(16). Shi TJ; Su D; Liu T; Tang KQ; Camp DG; Qian WJ; Smith RD Proteomics 2012, 12, 1074-1092. [PubMed: 22577010]

(17). Tang K; Page JS; Marginean I; Kelly RT; Smith RD J. Am. Soc. Mass Spectrom 2011, 22, 13181325. [PubMed: 21953185]

(18). Cox JT; Marginean I; Kelly RT; Smith RD; Tang KQ J. Am. Soc. Mass Spectrom 2014, 25, 2028-2037. [PubMed: 24676894]

(19). Cox JT; Kronewitter SR; Shukla AK; Moore RJ; Smith RD; Tang K Anal. Chem. 2014, 86, 9504-9511. [PubMed: 25222651]

(20). Chen Q; Yan G; Gao M; Zhang X Anal. Chem 2015, 87, 6674-6680. [PubMed: 26061007]

(21). Cifani P; Kentsis A Mol. Cell. Proteomics 2017, 16, 2006-2016. [PubMed: 28821601]

(22). Li S; Plouffe BD; Belov AM; Ray S; Wang X; Murthy SK ; Karger BL; Ivanov AR Mol. Cell. Proteomics 2015, 14, 1672-1683. [PubMed: 25755294] 
(23). Shen Y; Tolic N; Masselon C; Pasa-Tolic L; Camp DG; Hixson KK; Zhao R; Anderson GA; Smith RD Anal. Chem. 2004, 76, 144-154. [PubMed: 14697044]

(24). Sun L; Li Y; Champion MM; Zhu G; Wojcik R; Dovichi NJ Analyst 2013, 138, 3181-3188. [PubMed: 23591184]

(25). Sun L; Zhu G; Zhao Y; Yan X; Mou S; Dovichi N Angew. Chem., Int. Ed 2013, 52, 1366113664.

(26). Trauger SA; Go EP; Shen Z; Apon JV; Compton BJ; Bouvier ES; Finn MG; Siuzdak G Anal. Chem 2004, 76, 4484-4489. [PubMed: 15283591]

(27). Bekker-Jensen DB; Kelstrup CD; Batth TS; Larsen SC; Haldrup C; Bramsen JB; Sorensen KD; Hoyer S; Orntoft TF; Andersen CL; Nielsen ML; Olsen JV Cell Syst 2017, 4, 587-599. [PubMed: 28601559]

(28). Choi SB; Lombard-Banek C; Muñoz-LLancao P; Manzini MC; Nemes PJ Am. Soc. Mass Spectrom 2018, 29, 913-922.

(29). Lombard-Banek C; Moody SA; Nemes P Angew. Chem., Int. Ed 2016, 55, 2454-2458.

(30). Lombard-Banek C; Moody SA; Nemes P Front. Cell Dev. Biol 2016, 4, 100. [PubMed: 27761436]

(31). Sun LL; Dubiak KM; Peuchen EH; Zhang ZB; Zhu GJ; Huber PW; Dovichi N Anal. Chem 2016, 88, 6653-6657. [PubMed: 27314579]

(32). Virant-Klun I; Leicht S; Hughes C; Krijgsveld J Mol. Cell. Proteomics 2016, 15, 2616-2627. [PubMed: 27215607]

(33). Lombard-Banek C; Reddy S; Moody SA; Nemes P Mol. Cell. Proteomics 2016, 15, 2756-2768. [PubMed: 27317400]

(34). Milo R; Jorgensen P; Moran U; Weber G; Springer M Nucleic Acids Res. 2010, 38, D750-D753. [PubMed: 19854939]

(35). Yi L; Piehowski PD; Shi T; Smith RD; Qian WJ J. Chromatogr. A 2017, 1523, 40-48. [PubMed: 28765000]

(36). Zhu Y; Piehowski PD; Zhao R; Chen J; Shen YF; Moore RJ; Shukla AK; Petyuk VA; CampbellThompson M; Mathews CE; Smith RD; Qian WJ; Kelly RT Nat. Commun 2018, 9, 882. [PubMed: 29491378]

(37). Clair G; Piehowski PD; Nicola T; Kitzmiller JA; Huang EL; Zink EM; Sontag RL; Orton DJ; Moore RJ; Carson JP; Smith RD; Whitsett JA; Corley RA; Ambalavanan N; Ansong C Sci. Rep 2016, 6, 39223. [PubMed: 28004771]

(38). Huang EL; Piehowski PD; Orton DJ; Moore RJ; Qian WJ; Casey CP; Sun X; Dey SK; BurnumJohnson KE; Smith RD Endocrinology 2016, 157, 1307-1314. [PubMed: 26745641]

(39). Hughes CS; Foehr S; Garfield DA; Furlong EE; Steinmetz LM; Krijgsveld J Mol. Syst. Biol 2014, 10, 757. [PubMed: 25358341]

(40). Zhu Y; Clair G; Chrisler WB; Shen Y; Zhao R; Shukla AK; Moore RJ; Misra RS; Pryhuber GS; Smith RD; Ansong C; Kelly RT Angew. Chem., Int. Ed 2018, 57, 12370-12374.

(41). Shi T; Gaffrey MJ; Fillmore TL; Nicora CD; Yi L; Zhang P; Shukla AK; Wiley HS; Rodland KD; Liu T; Smith RD; Qian W Commun. Biol 2018, 1, 103. [PubMed: 30271983]

(42). Shi T; Fillmore TL; Sun X; Zhao R; Schepmoes AA; Hossain M; Xie F; Wu S; Kim JS; Jones N; Moore RJ; Pasa-Tolic L; Kagan J; Rodland KD; Liu T; Tang K; Camp DG 2nd; Smith RD; Qian WJ Proc. Natl. Acad. Sci. U. S. A 2012, 109, 15395-15400. [PubMed: 22949669]

(43). Shi T; Niepel M; McDermott JE; Gao Y; Nicora CD; Chrisler WB; Markillie LM; Petyuk VA; Smith RD; Rodland KD; Sorger PK; Qian WJ; Wiley HS Sci. Signaling 2016, 9, rs6.

(44). Niepel M; Hafner M; Pace EA; Chung M; Chai DH; Zhou LL; Schoeberl B; Sorger PK Sci. Signaling 2013, 6, ra84.

(45). Shi T; Sun X; Gao Y; Fillmore TL; Schepmoes AA; Zhao R; He J; Moore RJ; Kagan J; Rodland KD; Liu T; Liu AY; Smith RD; Tang K; Camp DG 2nd; Qian WJ J. Proteome Res 2013, 12, 3353-3361. [PubMed: 23763644]

(46). MacLean B; Tomazela DM; Shulman N; Chambers M; Finney GL; Frewen B; Kern R; Tabb DL; Liebler DC; MacCoss MJ Bioinformatics 2010, 26, 966-968. [PubMed: 20147306] 
(47). Wang HX; Qian WJ; Mottaz HM; Clauss TRW; Anderson DJ; Moore RJ; Camp DG; Khan AH; Sforza DM; Pallavicini M; Smith DJ; Smith RD J. Proteome Res 2005, 4, 2397-2403. [PubMed: 16335993]

(48). Yang Y; Shu YZ; Humphreys WG Chem. Res. Toxicol 2016, 29, 109-116. [PubMed: 26675335]

(49). Kim SC; Chen Y; Mirza S; Xu Y; Lee J; Liu P; Zhao Y J. Proteome Res 2006, 5, 3446-3452. [PubMed: 17137347]

(50). Turapov OA; Mukamolova GV; Bottrill AR; Pangburn MK Anal. Chem 2008, 80, 6093-6099. [PubMed: 18578500]

(51). Addona TA; Abbatiello SE; Schilling B; Skates SJ; Mani DR; Bunk DM; Spiegelman CH; Zimmerman LJ; Ham AJ; Keshishian H; Hall SC; Allen S; Blackman RK; Borchers CH; Buck C; Cardasis HL; Cusack MP; Dodder NG; Gibson BW; Held JM; Hiltke T; Jackson A; Johansen EB; Kinsinger CR; Li J; Mesri M; Neubert TA; Niles RK; Pulsipher TC; Ransohoff D; Rodriguez H; Rudnick PA; Smith D; Tabb DL; Tegeler TJ; Variyath AM; Vega-Montoto LJ; Wahlander A; Waldemarson S; Wang M; Whiteaker JR; Zhao L; Anderson NL; Fisher SJ; Liebler DC; Paulovich AG; Regnier FE; Tempst P; Carr SA Nat. Biotechnol 2009, 27, 633-641. [PubMed: 19561596]

(52). He J; Schepmoes AA; Shi T; Wu C; Fillmore TL; Gao Y; Smith RD; Qian WJ; Rodland KD; Liu T; Camp DG 2nd; Rastogi A; Tan SH; Yan W; Mohamed AA; Huang W; Banerjee S; Kagan J; Srivastava S; McLeod DG; Srivastava S; Petrovics G; Dobi A; Srinivasan A J. Transl. Med 2015, 13, 54. [PubMed: 25889691]

(53). Picotti P; Aebersold R Nat. Methods 2012, 9, 555-566. [PubMed: 22669653]

(54). Shi T; Su D; Liu T; Tang K; Camp DG 2nd; Qian WJ; Smith RD Proteomics 2012, 12, 1074 1092. [PubMed: 22577010]

(55). Fraser D; Powell RE J. Biol. Chem 1950, 187, 803-820. [PubMed: 14803465]

(56). Leon IR; Schwammle V; Jensen ON; Sprenger RR Mol. Cell. Proteomics 2013, 12, 2992-3005. [PubMed: 23792921]

(57). Zhang H; Liu T; Zhang Z; Payne SH; Zhang B; McDermott JE; Zhou JY; Petyuk VA; Chen L; Ray D; Sun S; Yang F; Chen L; Wang J; Shah P; Cha SW; Aiyetan P; Woo S; Tian Y; Gritsenko MA; Clauss TR; Choi C; Monroe ME; Thomas S; Nie S; Wu C; Moore RJ; Yu KH; Tabb DL; Fenyo D; Bafna V; Wang Y; Rodriguez H; Boja ES; Hiltke T; Rivers RC; Sokoll L; Zhu H; Shih I-M; Cope L; Pandey A; Zhang B; Snyder MP; Levine DA; Smith RD; Chan DW; Rodland KD; Investigators C; et al. Cell 2016, 166, 755-765. [PubMed: 27372738]

(58). Mertins P; Mani DR; Ruggles KV; Gillette MA; Clauser KR; Wang P; Wang X; Qiao JW; Cao S; Petralia F; Kawaler E; Mundt F; Krug K; Tu Z; Lei JT; Gatza ML; Wilkerson M; Perou CM; Yellapantula V; Huang KL; Lin C; McLellan MD; Yan P; Davies SR; Townsend RR; Skates SJ; Wang J; Zhang B; Kinsinger CR; Mesri M; Rodriguez H; Ding L; Paulovich AG; Fenyo D; Ellis MJ; Carr SA Nature 2016, 534, 55-62. [PubMed: 27251275]

(59). Zhang B; Wang J; Wang X; Zhu J; Liu Q; Shi Z; Chambers MC; Zimmerman LJ; Shaddox KF; Kim S; Davies SR; Wang S; Wang P; Kinsinger CR; Rivers RC; Rodriguez H; Townsend RR; Ellis MJ; Carr SA; Tabb DL; Coffey RJ; Slebos RJ; Liebler DC Nature 2014, 513, 382-387. [PubMed: 25043054]

(60). Shen Y; Zhao R; Berger SJ; Anderson GA; Rodriguez N; Smith RD Anal. Chem 2002, 74, 42354249. [PubMed: 12199598]

(61). Smith RD; Tang KQ; Shen YF Mol. BioSyst 2006, 2, 221-230. [PubMed: 16880940]

(62). Marginean I; Page JS; Tolmachev AV; Tang K; Smith RD Anal. Chem 2010, 82, 9344-9349. [PubMed: 21028835]

(63). Hossain M; Kaleta DT; Robinson EW; Liu T; Zhao R; Page JS; Kelly RT; Moore RJ; Tang K; Camp DG; Qian WJ; Smith RD Mol. Cell Proteomics 2011, 10, M00006. 


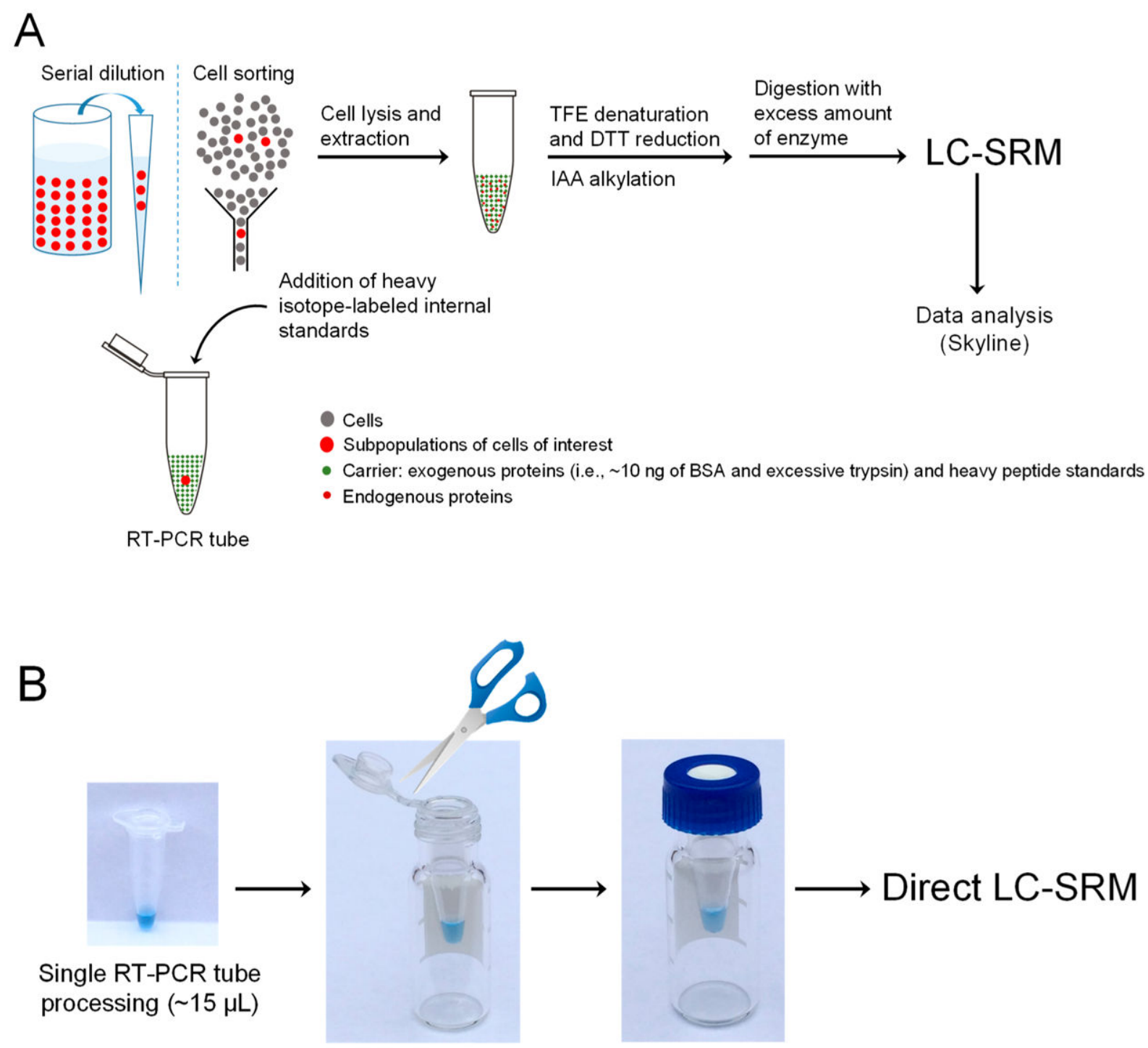

Figure 1.

(A) Schematic diagram of the cLC-SRM workflow. Small numbers of cells are collected into a RT-PCR tube precoated with $S$. oneidensis lysate digests. Exogenous proteins (i.e., $\sim 10 \mathrm{ng}$ of BSA and excessive trypsin) as well as heavy peptide standards added to the RTPCR tube are used as a carrier to prevent sample loss. An optimized single-tube TFE digestion method is used for sample processing to generate tryptic peptides. Sensitive LCSRM is then used for multiplexed quantification of target proteins. Skyline software is used for SRM data analysis. (B) Single-tube TFE digestion. A small number of cells are processed with minimal sample dilution in a processing volume of $\sim 15 \mu \mathrm{L}$ without sample transfer and cleanup. Prior to LC-SRM analysis, the cap of the RT-PCR tube is removed and the tube is then inserted into a sample vial to avoid sample transfer loss. 

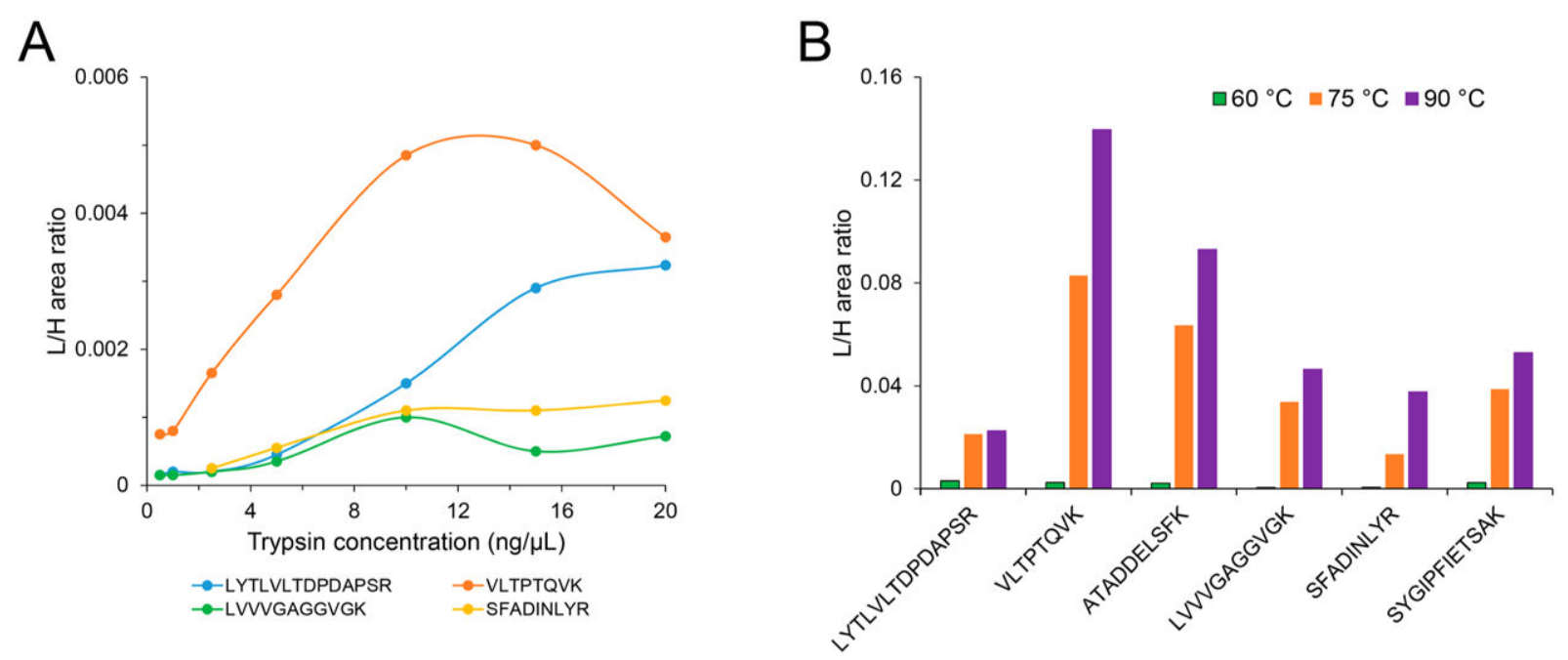

Figure 2.

Optimization of trypsin digestion efficiency. (A) Trypsin amount: $\sim 10 \mathrm{ng}$ of MCF7 cell lysates were processed with the standard TFE digestion protocol using different concentrations of trypsin $(1,2.5,5,10,15,20 \mathrm{ng} / \mu \mathrm{L})$. (B) Denaturing temperature: $\sim 10 \mathrm{ng}$ of MCF7 cell lysates were processed at different denaturing temperatures $\left(60,75,90{ }^{\circ} \mathrm{C}\right)$ with $15 \mathrm{ng} / \mu \mathrm{L}$ of trypsin. Three high-abundance proteins (PEBP1, H/K/NRAS, and NRAS) and five high-abundance proteins (PEBP1, H/K/NRAS, K/NRAS, NRAS, and GRB2) were measured to optimize the trypsin amount and the denaturing temperature, respectively. Two processing replicates were used for each condition with the addition of $\sim 100 \mathrm{fmol}$ of heavy peptide standards per replicate. Average $\mathrm{L} / \mathrm{H}$ ratios were used for plotting. 


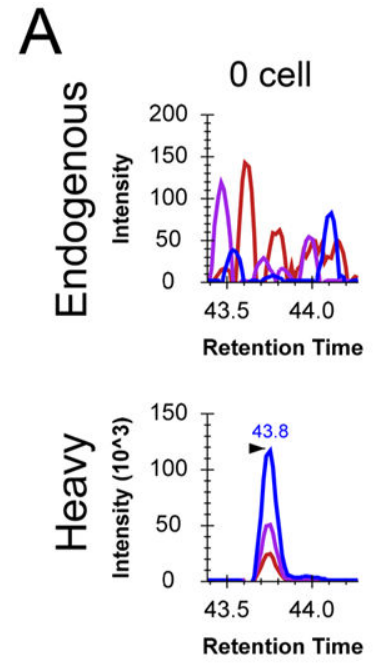

B

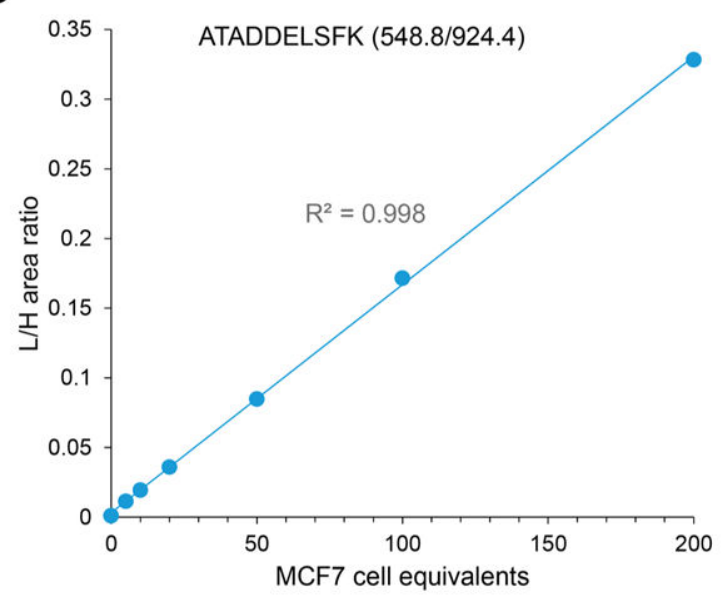

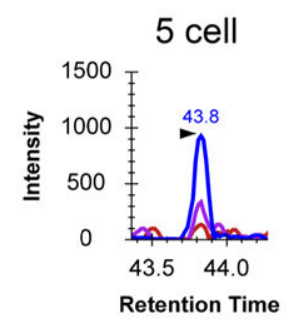
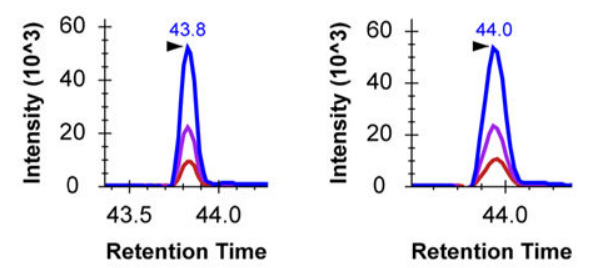

Retention Time
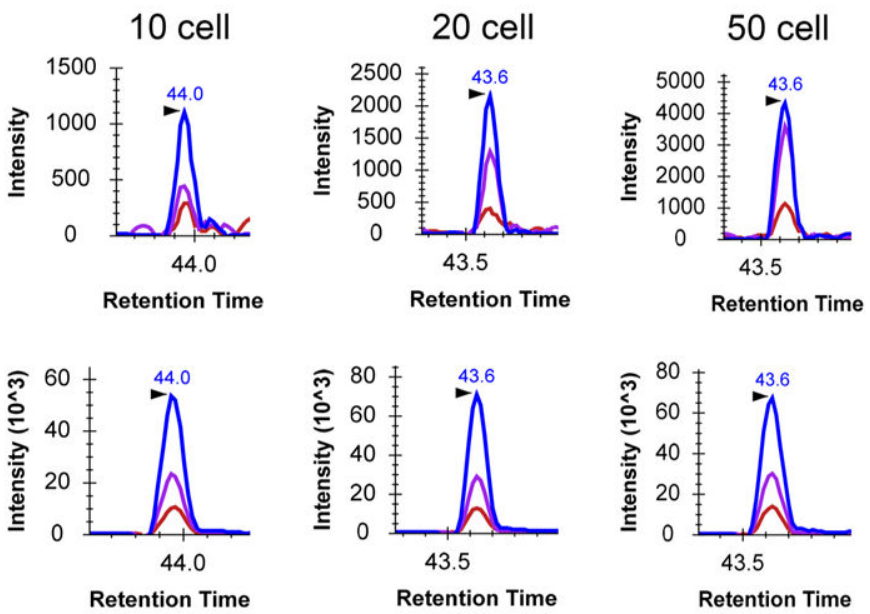

Figure 3.

Sensitivity and accuracy of cLC-SRM for protein quantification in small amounts of MCF7 cell lysates. (A) Extracted ion chromatograms (XICs) of transitions monitored for ATADDELSFK derived from GRB2 at different numbers of MCF7 cell equivalents: 548.8/924.4 (blue), 548.8/853.4 (purple), 548.8/738.4 (chestnut). Calibration curves for quantifying high-abundance GRB2 (B) and moderate-abundance PTPN11 (C) with the use of the best responsive interference-free transitions, ATADDELSFK (548.8/924.4) for GRB2 and SNPGDFTLSVR (596.9/496.3) for PTPN11. Three and two SRM replicates were performed for 0-10 and 20-200 MCF7 cell equivalents, respectively. 

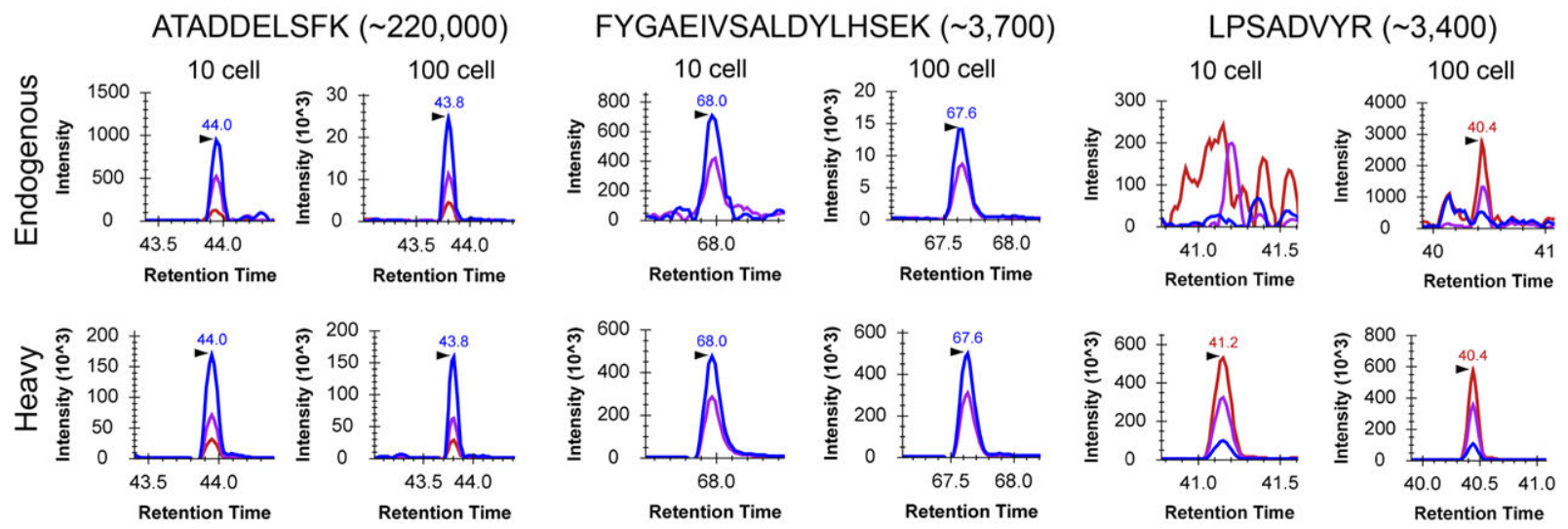

Figure 4.

Comparison of SRM signal between FACS-isolated 10 and 100 intact MCF7 cells measured by cLC-SRM. Each sample consists of two biological replicates with the addition of $\sim 30$ fmol of heavy peptide standards per replicate. XICs of transitions monitored for ATADDELSFK derived from GRB2: 548.8/924.4 (blue), 548.8/853.4 (purple), 548.8/738.4 (chestnut); XICs of transitions monitored for FYGAEIVSALDYLHSEK derived from AKT1: 648.0/897.9 (blue), 648.0/816.4 (purple), 648.0/283.1 (chestnut); XICs of transitions monitored for LPSADVYR derived from SOS1: $460.7 / 807.4$ (blue), 460.7/710.3 (purple), 460.7/404.2 (chestnut). 


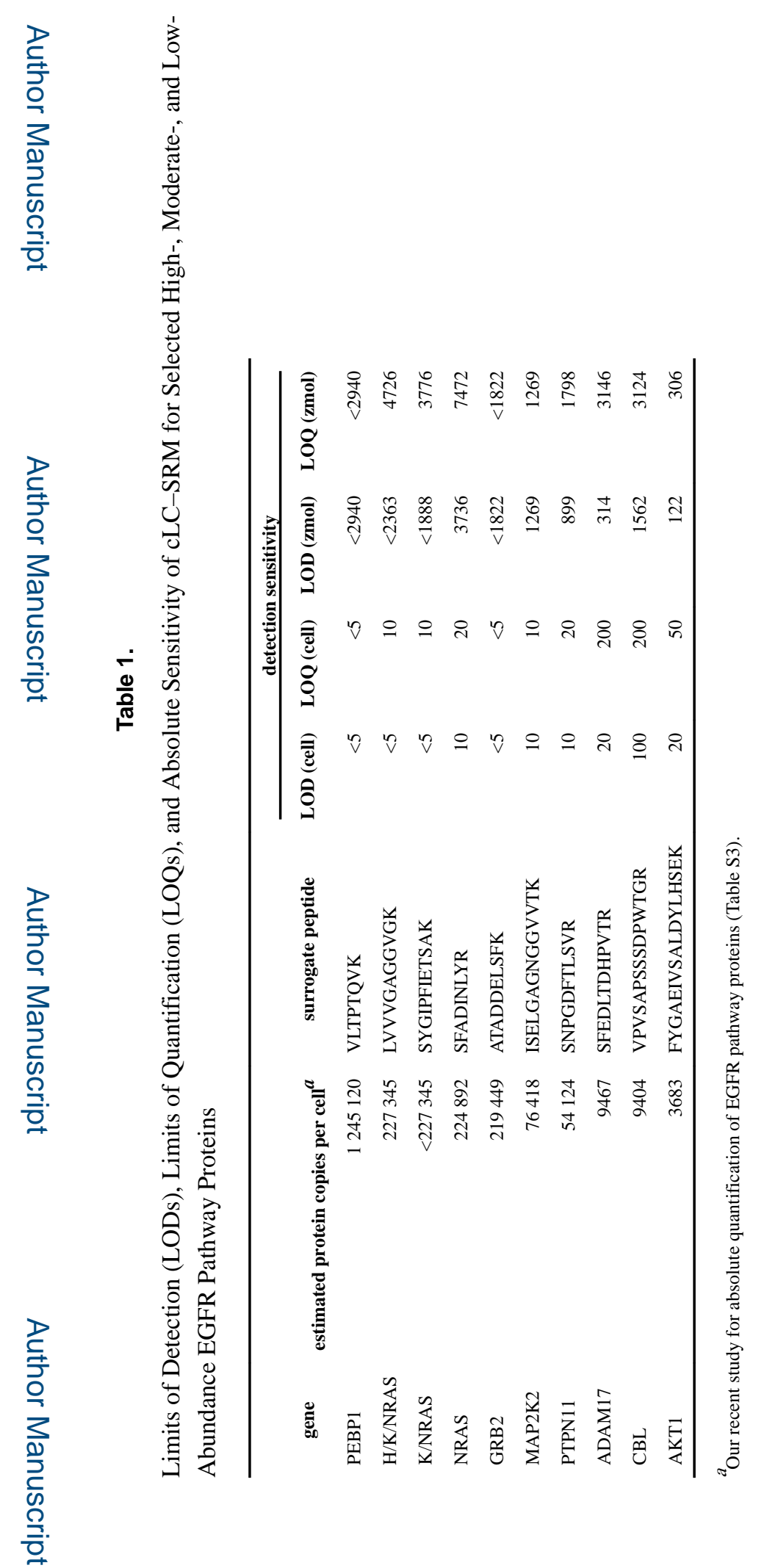

Anal Chem. Author manuscript; available in PMC 2019 June 07. 


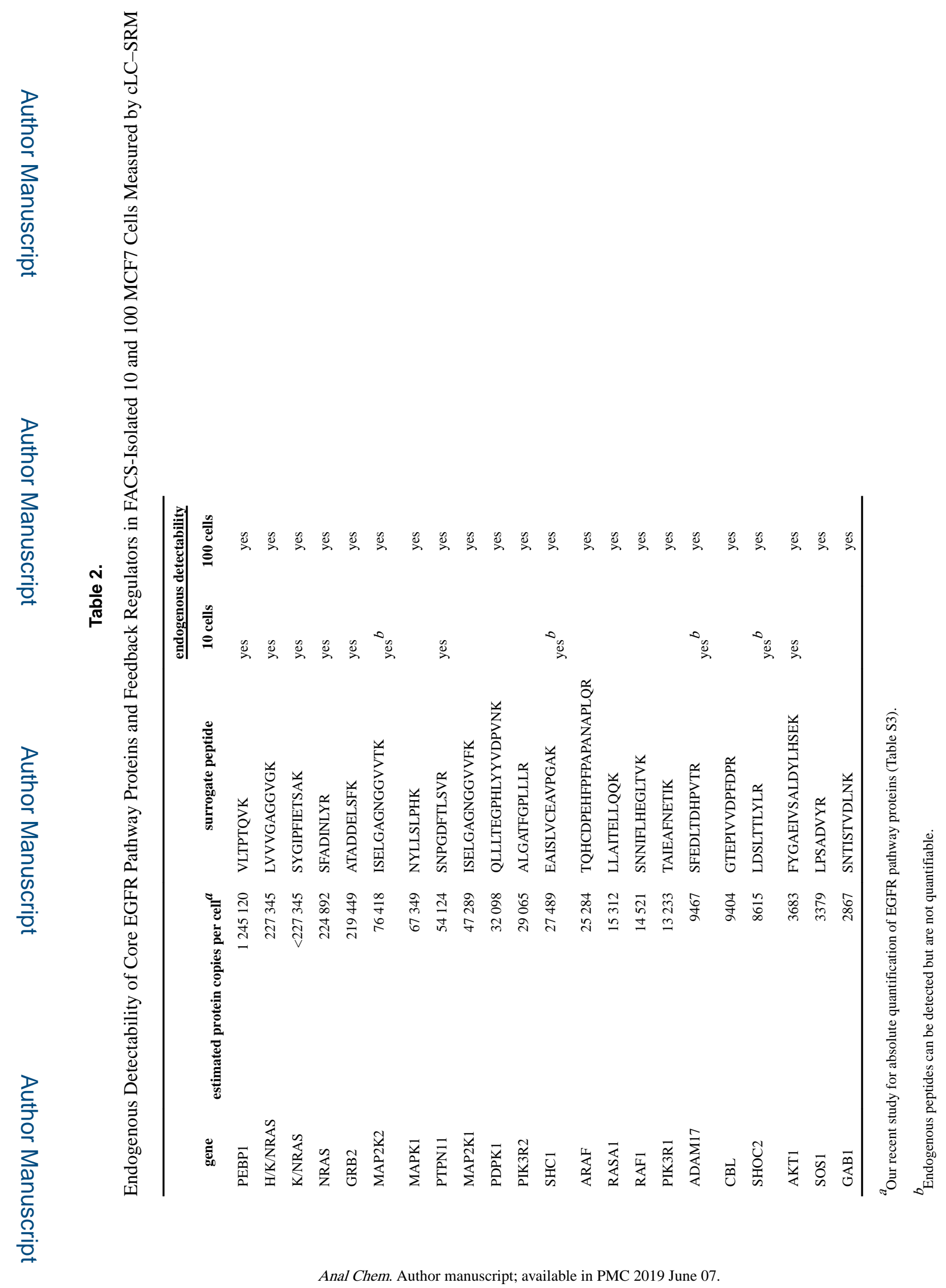

